\title{
Drying temperature and water content-strength correlations
}

Brendan C. O'Kelly PhD, FTCD, CEng, CEnv, MICE

Associate Professor, Department of Civil, Structural and Environmental

Engineering, Museum Building, Trinity College Dublin, Dublin, Ireland

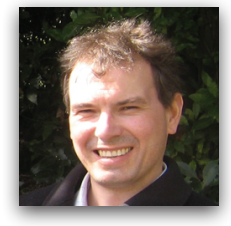

For water content determinations on organic soils, several researchers have adopted lower oven-drying temperatures in the range $35-90^{\circ} \mathrm{C}$ (instead of the standardised range for mineral soils of $100-110^{\circ} \mathrm{C}$ ) in order to prevent possible charring, oxidation and (or) vaporisation of substances other than water. However, at too low a temperature, not all of the relevant water is driven off. One major consequence of using such a wide range of drying temperatures for more sensitive materials is to produce considerable disparity in interpolated index values and in deduced correlations between water content and other engineering properties. This paper discusses the pros and cons regarding the ovendrying temperature adopted for routine water content determinations on organic sludges and residues. It concludes by recommending a standardised oven temperature of $105-110^{\circ} \mathrm{C}$ or $105 \pm 5^{\circ} \mathrm{C}$, a $24-\mathrm{h}$ drying period and a suggested minimum wet specimen mass of $50 \mathrm{~g}$.

\section{Notation}

AMC

$I_{\mathrm{LN}}$

LL

LOI

PL

WTR

$a$

$b$

$m_{\text {ref }}$ and $m_{t^{\circ} \mathrm{C}}$

$S_{\text {ur }}$

$S_{\mathrm{ur}_{(\mathrm{LL})}}$ and $S_{\mathrm{ur}_{(\mathrm{PL})}}$

$w$

$w_{105^{\circ} \mathrm{C}}$ and $w_{t^{\circ} \mathrm{C}}$

$\alpha$

$\alpha_{105^{\circ} \mathrm{C}}$ and $\alpha_{110^{\circ} \mathrm{C}}$

$\beta$

$\beta_{105^{\circ} \mathrm{C}}$ and $\beta_{110^{\circ} \mathrm{C}}$
Apparent moisture content ratio after

Skempton and Petley (1970)

Modified liquidity index

Liquid limit

Loss on ignition

Plastic limit

Water-treatment residue material

Water content (as \%) for $s_{\mathrm{ur}}=1 \mathrm{kPa}$

Gradient of $\log w$-log $s_{\text {ur }}$ correlation

Equilibrium dry masses for a reference oven temperature and a lower drying temperature of $t^{\circ} \mathrm{C}$, respectively

Saturated remoulded undrained shear strength Saturated remoulded undrained strengths at

LL and PL, respectively

Gravimetric water content (as \%)

Dimensionless water content values for temperatures of $105^{\circ} \mathrm{C}$ and $t^{\circ} \mathrm{C}$, respectively Water content parameter

Water content parameter values for reference temperatures of $105^{\circ} \mathrm{C}$ and $110^{\circ} \mathrm{C}$, respectively Gradient of parameter $\alpha$ against drying temperature trend line

Gradients of parameter $\alpha$ against drying temperature trend lines based on equilibrium dry masses at $105^{\circ} \mathrm{C}$ and $110^{\circ} \mathrm{C}$, respectively

\section{Introduction}

Municipal sludges and residues generally have very or extremely high values of water content. It is widely accepted that water content alone is an inadequate and often unreliable measure in assessing, from a geotechnical standpoint, that satisfactory levels of dewatering have been achieved for organic sludges and residues. This is necessary, for example, in order to reduce associated transportation and landfill disposal costs and to achieve adequate shear strength for efficient handling, trafficability and geotechnical stability of landfill slopes (O'Kelly and Quille, 2010). There has also been a trend toward adopting the fall-cone and shear-vane test methods as quick means of determining the shear strength in order to assess whether such materials have been adequately dewatered before leaving municipal or industrial works and, again, for example, by the landfill operator before accepting the dewatered material for disposal (O'Kelly, 2014). However, as illustrated in Figure 1, for a given value of water content, the mobilised remoulded undrained shear strength $\left(s_{\text {ur }}\right)$ depends on the material (its grading, composition and mineralogical properties, particularly those of the clay fraction (Trauner et al., 2005; Wood, 1990), organic content along with type of chemical and biological treatments applied and level of bioactivity); physical state (degree of compaction and saturation); and method of strength measurement, including the test-specimen size, stress and boundary conditions, shearing mode and rate (O'Kelly, 2013a, 2013b, 2014). Where liquid limit and plastic limit data are available, liquidity index is often determined and used instead of water content for correlation 
Drying temperature and water content-

strength correlations

O'Kelly

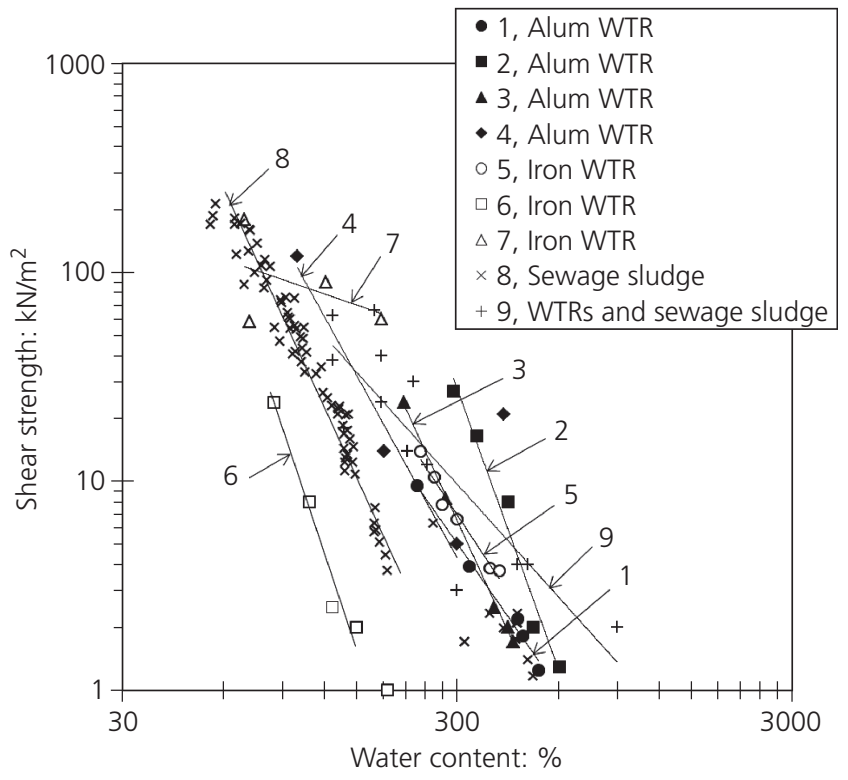

Figure 1. Undrained strength against water content correlations for water-treatment residue (WTR) and sewage sludge materials Nos. 1 and 5, Novak and Calkins (1975); nos. 2, 3 and 6, Wang et al. (1992); nos. 4 and 7, Wichmann and Riehl (1997); no. 8, O’Kelly (2006); no. 9, Geuzens and Dieltjens (1991).

with shear strength. However, the data in Figure 1 are presented in terms of water content since the values of these consistency limits were reported for only two of the five studies considered. Included in the figure are undrained strength data deduced from fall-cone, miniature vane and triaxial compression apparatus for alum and iron water-treatment residues (WTRs) and municipal sewage sludge materials. The premise of this paper is that the wide range of oven temperature values adopted by different researchers for water content determinations can significantly impact on water contentstrength correlations.

In geotechnical literature, water content $(w)$ is defined as the mass ratio of pore water to solids, expressed as a percentage. The definitive procedure for the laboratory determination of water content is the oven-drying method. Oven temperature and drying period are of great importance, influencing the measurement result, whereas atmospheric pressure and humidity are of secondary importance. For some materials, such as highly organic soils, soils in which the pore water contains dissolved solids, or those containing significant amounts of halloysite, mica, montmorillonite, gypsum or other hydrated materials, the oven-drying method may not yield reliable water content values.

For industry-standard water content determinations, the removal of pore water is required and excludes adsorbed water on the surface of the solids and any water of crystallisation. Other phenomena, such as the permanent removal of inter-sheet water in, for instance, halloysite $10 \AA$ (Mitchell, 1993), may also occur, although this is not considered as pore water either. For mineral soils, the removal of pore water is achieved by oven drying representative specimens at temperatures of $105 \pm 5^{\circ} \mathrm{C}$ (ASTM D2974; ASTM, 2007) or $105-110^{\circ} \mathrm{C}(\mathrm{BS} 1377-2$; BSI, 1990a) for a period of at least $16 \mathrm{~h}$, or longer as necessary, until there is no change in the specimen mass after further drying periods in excess of $1 \mathrm{~h}$. Apart from gypsum, and some tropical clays, water of crystallisation is generally not removable by oven drying at temperatures of up to $105-110^{\circ} \mathrm{C}$ (Head, 1997).

However, in the case of organic sludges and residues, some solid organic matter may potentially char or oxidise (decompose) and vaporisation of substances other than pore water (e.g., organic solvents, alcohols, greases, oils, aromatic components) may also occur at these elevated temperatures. This would result in the measurement of apparently higher values of water content (O'Kelly, 2005 b 2005d). By contrast, at too low a temperature, not all of the pore water would be driven off (O'Kelly, 2004a, 2005c).

The aims of the present study are:

(a) For different temperatures, investigate the drying rate and period required for oven drying of municipal sewage sludge and WTR material;

(b) Study the impact of oven-drying temperature on correlations between water content and undrained strength;

(c) Recommend a suitable combination of oven temperature and drying period for routine water content determinations on organic sludges and residues.

In the present investigation, oven-drying tests were performed over the temperature range $80-110^{\circ} \mathrm{C}$. Testing commenced at $80^{\circ} \mathrm{C}$ since MacFarlane and Allen (1965) reported that charring and oxidation of some organic matter, specifically coarse fibres in a fibrous peat material, became increasingly evident for temperatures in excess of $\sim 85^{\circ} \mathrm{C}$. O'Kelly $(2005 \mathrm{~b}, 2005 \mathrm{~d}$ ) also reported that for eight organic soils having loss on ignition (LOI) values of 3-93\%, some slight charring and oxidation of susceptible organic matter commenced within the temperature range $80-90^{\circ} \mathrm{C}$. Gravity-convection and forced-draft type ovens are both used in the present investigation in order to investigate whether the method of air circulation within the oven chamber has any significant effect on measured values of water content. Finally, the significance of adopting different ovendrying temperatures for routine water content determinations is considered in terms of its impact on interpolated index values and correlations between water content and undrained strength. To the author's knowledge, this is the first study to investigate such effects.

\section{Test materials}

Oven-drying tests were performed on moderately degraded municipal sewage sludge material obtained from the Tullamore Municipal Wastewater Works (County Offaly, Ireland) and on alum WTR material derived from the production of potable water at Ballymore Eustace Water Treatment Works (County Dublin, 
Environmental Geotechnics

Volume 1 Issue EG2
Drying temperature and water content-

strength correlations

O'Kelly
Ireland). Comprehensive descriptions of the geotechnical and hydraulic properties of these materials have been reported for the sewage sludge by O'Kelly (2004b, 2005a, 2006, 2008a, 2013b) and the WTR material by O'Kelly $(2008$ b , 2014) and O'Kelly and Quille $(2009,2010)$. The oven-drying characteristics of the fraction of the sewage sludge material passing the $425-\mu \mathrm{m}$ sieve, which had an LOI of $70 \%$, have been reported previously by O'Kelly (2004a, 2005b, 2005 c), employing the same convection oven as that used in the present investigation. The oven-drying characteristics of the coarse fibrous fraction ( $\sim 10 \%$ of the material's total dry mass) retained after wet sieving the bulk material on the $425-\mu \mathrm{m}$ sieve are investigated in the present study. This fraction was mainly composed of cellulose, hemicellulose and lignin plant fibres, with any Magnafloc LT22S additive that had been added for chemical conditioning of the sludge at the municipal works substantially diluted during the laboratory wet-sieving process. Scanning electron micrographs reported by O'Kelly (2005a) indicated that the solids phase comprised aggregate flocs of clay mineral particles, coarse and fine organic fibres, colloidal organic matter (carbohydrates, proteins and lipids; Raunkjaer et al., 1994) and pathogenic organisms. High-intensity peaks from X-ray diffraction analysis for the mineral solids were interpreted as quartz, calcite and kaolinite, although there was also the likelihood of other trace minerals at concentrations of less than $1-2 \%$ by mass. The pore fluid had a viscous gel-like nature, caused by the high concentration of dissolved solids, high bonding or adsorption of the liquid phase within and around the aggregate flocs, and some form of biological coagulation between the pore fluid and organic solids (O'Kelly, 2013b). Comparisons in the present study between the oven-drying characteristics of the two fractions of the sewage sludge material would enable the effect of the coarse organic fibres on the drying response to be determined.

For the WTR material, the source water under treatment was obtained from an upland catchment of saturated peat overlying granite bedrock in the Dublin and Wicklow mountains, Ireland. The solids phase of the WTR material was almost exclusively composed of aggregate flocs of colloidal organic matter, clay mineral particles and included alum Chemifloc 4140 coagulant and Magnafloc LT25 polyelectrolyte. These chemicals had been added during the purification processes and also to achieve better dewatering efficiency of the WTR slurry at the treatment works. In terms of chemical composition, the WTR material was composed of $24-28 \%$ aluminium and $\sim 3 \cdot 5 \%$ Magnafloc by dry solids mass. Refer to O'Kelly (2008b, 2010, 2014) and O'Kelly and Quille $(2009,2010)$ for further details.

LOI values of $57 \%$ and $\sim 100 \%$ were determined for the WTR material and coarse fibrous fraction of the sewage sludge, respectively, by igniting test specimens of the powdered materials (previously oven dried to achieve equilibrium mass at $105^{\circ} \mathrm{C}$ ) in a muffle furnace at $440^{\circ} \mathrm{C}$ over an 18 -h period, in accordance with BS1377-3 (BSI, 1990b). Respective fibre contents (percentage of material by dry mass retained on the $150-\mu \mathrm{m}$ sieve) were measured at $0 \%$ and $100 \%$, in accordance with ASTM D1997-91 (ASTM, 2008).

\section{Experimental method}

For the two study materials, samples were thoroughly remoulded and sub-divided to obtain homogeneous specimens of nominally $50 \mathrm{~g}$ in wet mass for oven-drying tests. These specimens were placed in tarred aluminium cups within a 14-L chamber capacity gravity-convection oven (Memmert Universal model UNB 100) which provided thermostatic control of the chamber temperature to $\pm 1 \cdot 5^{\circ} \mathrm{C}$ of the set temperature value. The equilibrium dry masses of the specimens were determined for set oven temperatures, commencing with $80^{\circ} \mathrm{C}$ and increasing in six steps up to a maximum of $110^{\circ} \mathrm{C}$. In this manner, the effects of increasing oven temperature could be investigated for specific values of temperature and drying period within this temperature range. During the course of these tests, the specimens were periodically removed from the oven, cooled in desiccators to ambient laboratory temperature and the dry masses of the specimens recorded to $0.01 \mathrm{~g}$. The use of desiccators is important since considerable systematic errors may arise if the test material were hygroscopic and absorbed water from surrounding air after drying, but before it could be weighed. The oven-drying process was then continued by replacing the specimens in the same locations within the oven chamber. Note that repeated sequences of heating and cooling may affect the samples' structure. Although this was not apparent in the present study, in other instances, unavoidable, simultaneous decomposition of the material may occasionally occur; for example, following removal from water of crystallisation. Over the course of the drying process, the chamber temperature was set and maintained for different periods at $80^{\circ} \mathrm{C}, 90^{\circ} \mathrm{C}, 100^{\circ} \mathrm{C}, 105^{\circ} \mathrm{C}$ and $110^{\circ} \mathrm{C}$, with the temperature increasing from one step to the next. A similar sequence of $60^{\circ} \mathrm{C}$, $85^{\circ} \mathrm{C}, 100^{\circ} \mathrm{C}, 105^{\circ} \mathrm{C}$ and $110^{\circ} \mathrm{C}$ was used in oven-drying testing of various organic soils by Skempton and Petley (1970). In the present investigation, drying tests commenced at $80^{\circ} \mathrm{C}$, below the reported value of $\sim 85^{\circ} \mathrm{C}$ for which some charring of organic matter became increasingly evident for a fibrous peat studied by MacFarlane and Allen (1965). O'Kelly (2005b, 2005d) also reported that, for eight organic soils investigated, some slight charring and oxidation had commenced in the range $80-90^{\circ} \mathrm{C}$. Full evaporation of the pore water occurs at $100^{\circ} \mathrm{C}$. The standardised oven-drying temperature is $105^{\circ} \mathrm{C}$, with $110^{\circ} \mathrm{C}$ specified as the upper limit, for water content determinations on mineral soils (BS1377-2: BSI, 1990a; ASTM D2974: ASTM, 2007). Hence it follows that the specimen equilibrium dry mass would comprise the following:

- At $80^{\circ} \mathrm{C}$, the mass of solids, any residual pore water less any vaporisation of volatile substances;

- At $90^{\circ} \mathrm{C}$, the mass of solids, less any reduction that may have occurred due to charring, oxidation and vaporisation of volatile substances and a potentially reduced amount of residual pore water;

- At $100^{\circ} \mathrm{C}, 105^{\circ} \mathrm{C}$ and $110^{\circ} \mathrm{C}$, the mass of solids, less any reduction due to charring, oxidation and vaporisation of volatile substances.

In a second series of drying tests, a larger forced-draft oven was used to investigate whether the method of air circulation within 


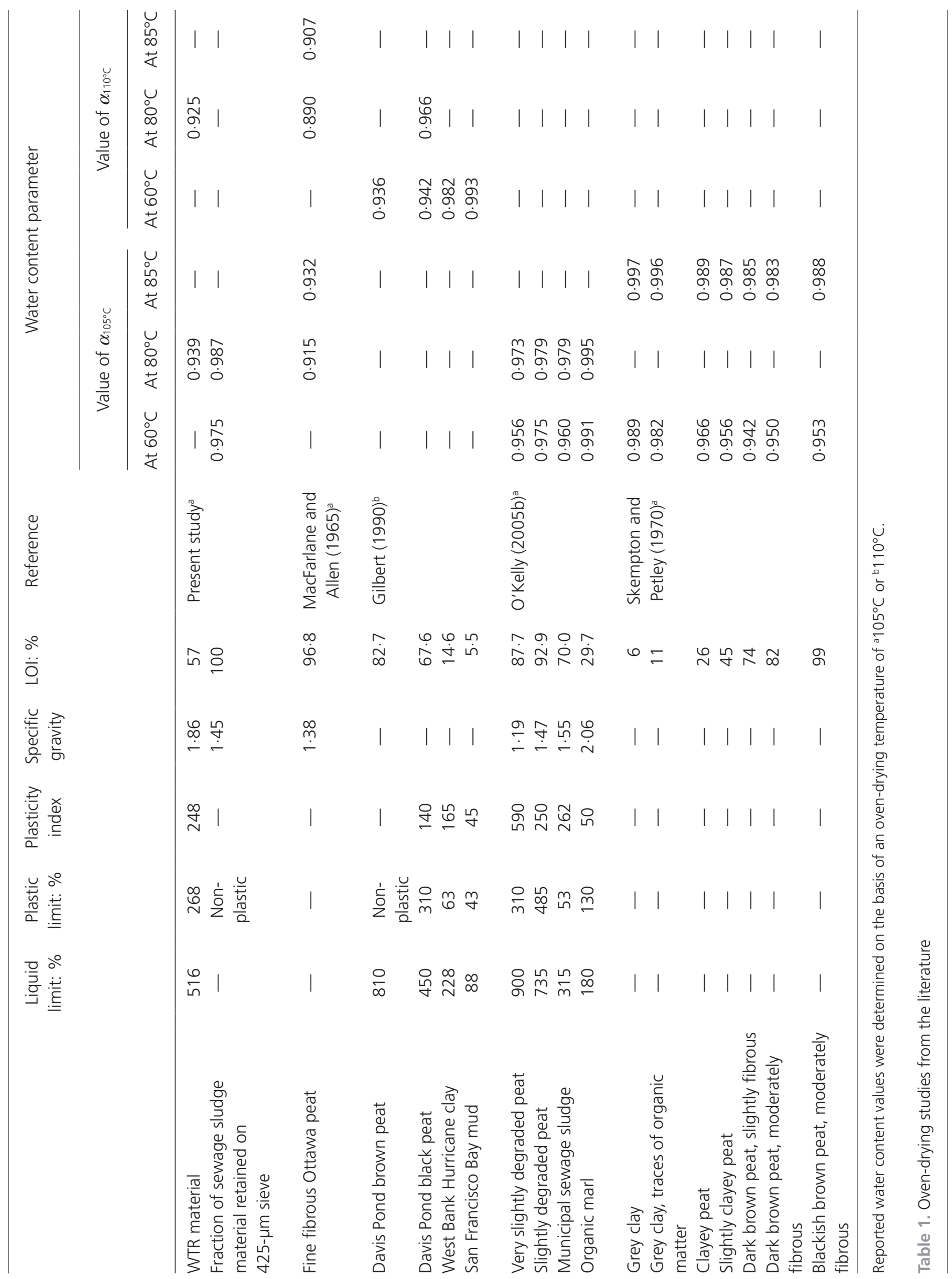


the oven chamber had any significant effect on the specimen dry mass and required drying period, and, hence, on measured values of water content, for $105^{\circ} \mathrm{C}$. The 133 -L chamber capacity forced-draft oven used (ELE International model N150CF, with a rated power of $1500 \mathrm{~W}$ ) provided thermostatic control of the chamber temperature to $\pm 1^{\circ} \mathrm{C}$ of the set temperature value, which was calibrated using an alcohol thermometer.

The WTR material was found to have unusual oven-drying behaviour in that the test-specimen mass did not show any signs of equilibrating after a 48-h drying period. WTR test specimens of nominally 20,50 and $100 \mathrm{~g}$ in wet mass were oven dried at $105^{\circ} \mathrm{C}$ over an extended period of 34 days using the forced-draft oven in order to investigate this behaviour further.

Correlations were also established between water content determined on the basis of different oven temperatures and remoulded undrained strength for the WTR material. Undrained strength data extending well beyond the plastic range were determined using three approaches: the $80 \mathrm{~g}-30^{\circ}$ fall-cone liquid limit apparatus (BS1377-2; BSI, 1990a), miniature vane and triaxial compression tests. In the vane tests, a $25-\mathrm{mm}-$ by- $25-\mathrm{mm}$ cruciform vane was torqued under a vane-head rotation of $9 \%$ min. In the triaxial tests, 38-mm-diameter-by-76-mm-long test specimens were compressed at an axial strain rate of $2 \% / \mathrm{min}$ under an applied cell pressure of $100 \mathrm{kPa}$. Batches of the WTR material were prepared to different values of water content by allowing wet material to air dry for different periods at ambient laboratory temperature of $21^{\circ} \mathrm{C}$, with frequent mixing to maintain a uniform paste. Once air-dried sufficiently, the batches were stored in separate airtight containers for a period of at least $48 \mathrm{~h}$ to achieve uniformity of water content. The test specimens were prepared by pressing the freshly remoulded material into moulds of the same dimensions using the kneading technique, taking care to minimise air voids. Although the water content of most of the triaxial specimens $(w=215-285 \%)$ was below the measured plastic limit value of $268 \%$ (Table 1), nevertheless, the material was readily remoulded at these lower values of water content. This behaviour will be examined later in the Discussion section of this paper. The British standard method for determination of the undrained shear strength in triaxial compression (BS1377-7; BSI, 1990c) specifies a rate of axial deformation to produce specimen failure with a period of $5-15 \mathrm{~min}$. Hence a strain rate of $2 \% / \mathrm{min}$ was used in these triaxial tests since peak deviatoric stress was generally mobilised at between $20 \%$ and $30 \%$ axial strain. Further details on strength testing of sludges and residues using these test methods are reported by O'Kelly (2013a, 2013b, 2014).

\section{Experimental results}

Figure 2 shows the recorded dry masses of four WTR test specimens plotted against the cumulative drying period. Over the course of the oven-drying process, the chamber temperature had been maintained for different periods at $80^{\circ} \mathrm{C}, 90^{\circ} \mathrm{C}, 100^{\circ} \mathrm{C}, 105^{\circ} \mathrm{C}$ and $110^{\circ} \mathrm{C}$, with the temperature increasing from one step to the next. The data in

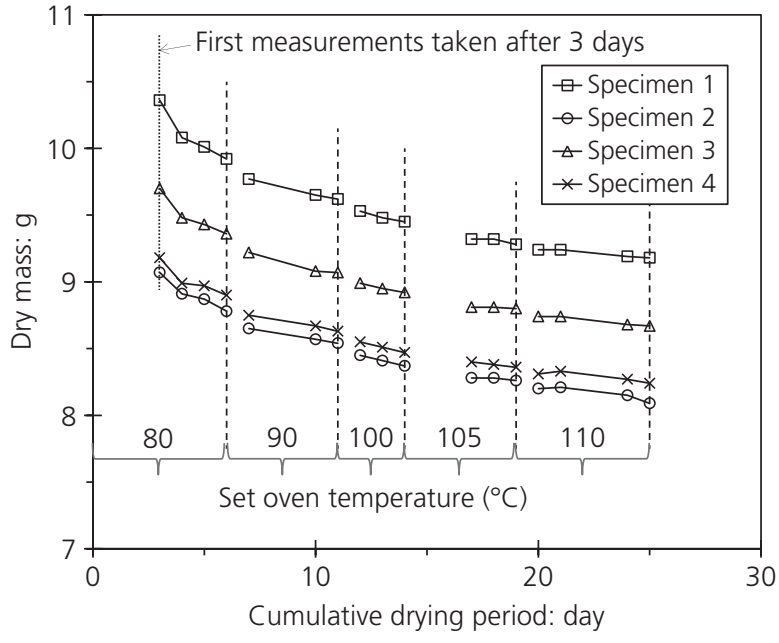

Figure 2. Drying of WTR material in a gravity-convection oven for step increases in drying temperature

the figure indicate a trend of decreasing specimen dry mass with both increasing oven temperature and drying period. According to BS1377-2 (BSI, 1990a), after the initial 24-h drying period, all of the test specimens would have been deemed to have achieved a dry state. This is deemed satisfied where the difference in successive weighing of a test specimen over a 4-h interval does not exceed $0 \cdot 1 \%$ of its initial wet mass. It was also observed that the WTR material had rather unusual drying behaviour in that it became brittle and disintegrated into irregular angular fragments. O'Kelly (2008b, 2014) also reported this behaviour for oven drying of the same WTR material.

Figure 3 compares the drying response of the WTR material in gravity-convection and forced-draft ovens at $105^{\circ} \mathrm{C}$ for test specimens having initial wet masses of nominally $100 \mathrm{~g}$. Experimental data for specimens nominally $50 \mathrm{~g}$ in initial wet mass are presented in Supplementary Figures A and B. As expected, Figure 3(a) shows that the evaporation rate achieved using the forced-draft oven was initially significantly greater. The rate of mass loss over the 1- to 3-day oven-drying period was slightly greater for the gravity-convection oven (Figure 3(b)). The latter presumably occurred since marginal amounts of residual pore water were still present in material dried using the gravity-convection oven on account of its slower drying rate and also because of the colloidal nature and hence slower drying rate of the material itself. After the initial 3-day drying period, the rates of mass loss for the gravity-convection and forced-draft ovens were very similar. Hence the method of air circulation (either by gravity-convection or forced-draft) within the oven chamber appears to significantly affect the pore-water evaporation rate only, with similar levels of charring and oxidation occurring. However, it should be noted that, as set out in BS1377-2 (BSI, 1990a), the specimen dry mass 


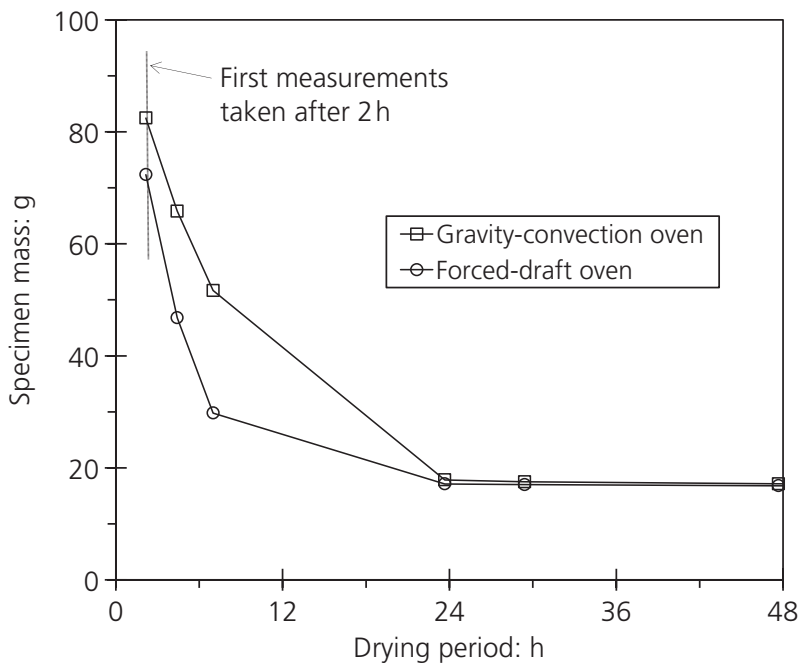

(a)

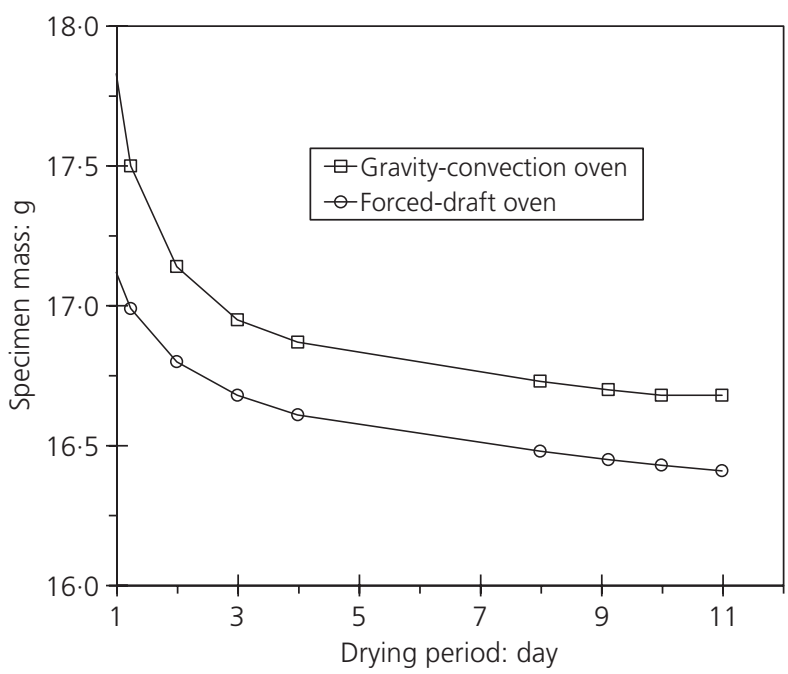

(b)

Figure 3. Drying response of WTR material at $105^{\circ} \mathrm{C}$ for initial wet specimen masses of $100 \mathrm{~g}$. (a) Initial 48-h drying period. (b) Response after initial 24-h drying period.

had equilibrated sufficiently after the initial 24-h drying period at $105^{\circ} \mathrm{C}$ for the purpose of water content determinations.

Figure 4 shows the outcome of drying tests performed in the forced-draft oven at $105^{\circ} \mathrm{C}$ on WTR test specimens having initial wet masses of nominally $50 \mathrm{~g}$. Experimental data for specimens nominally 20 and $100 \mathrm{~g}$ in initial wet mass are presented in Supplementary Figures C and D. Mass was continuously lost from the specimens over the 34-day drying period. By comparing the gradient of the drying trend lines (i.e., $-0.0023,-0.0059$ and -0.0107 for specimens of 20,50 and $100 \mathrm{~g}$ initial wet mass, respectively), it was concluded that the amount of oxidation occurring over this time period was approximately directly proportional to the mass of the dried specimen. However, the gradient eventually has to fall off.

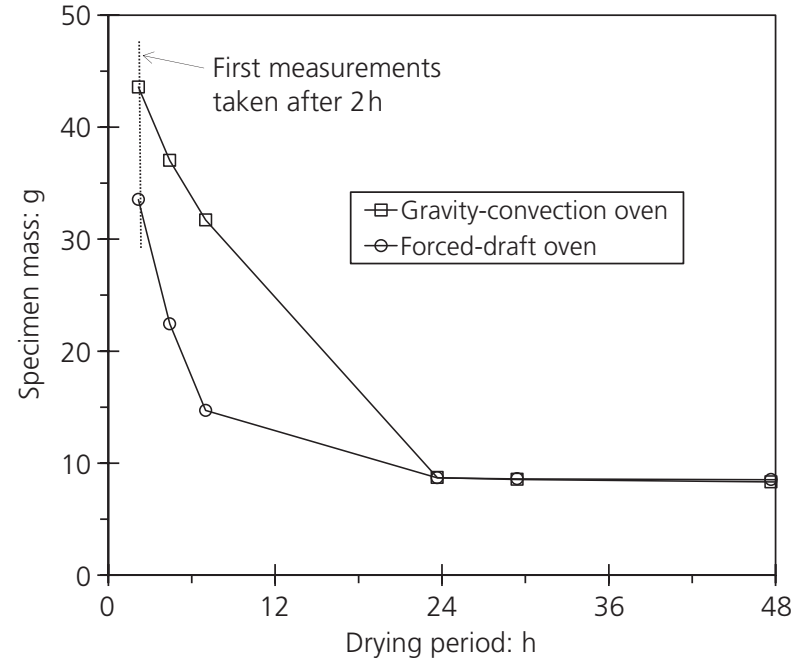

Supplementary Figure A. Initial 48-h drying response of WTR specimens having initial wet masses of $50 \mathrm{~g}$ for gravity-convection and forced-draft ovens set at $105^{\circ} \mathrm{C}$

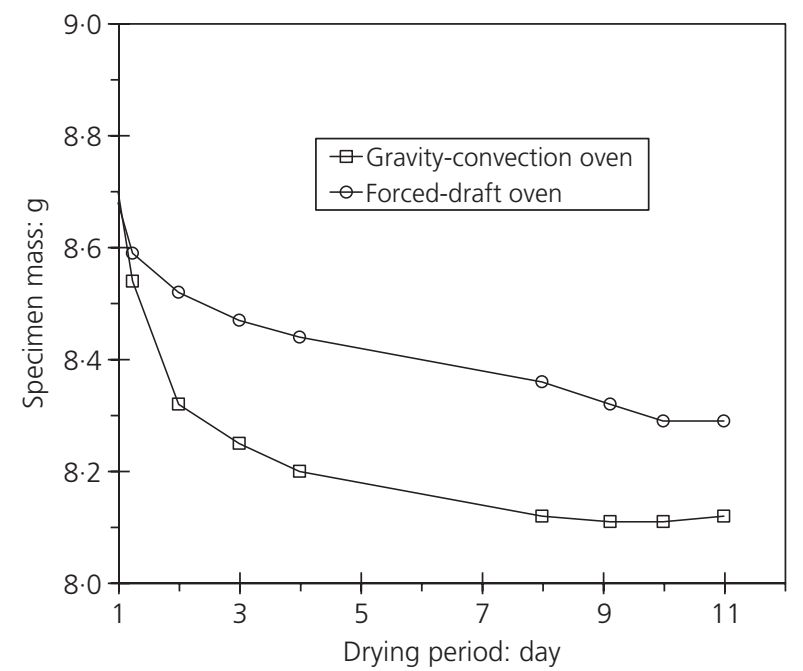

Supplementary Figure B. Drying response of WTR specimens having initial wet masses of $50 \mathrm{~g}$ after an initial 24-h drying period in gravity-convection and forced-draft ovens set at $105^{\circ} \mathrm{C}$

\section{Experimental analyses}

Oven-drying behaviour

The drying data for the WTR material and coarse fibrous fraction of the sewage sludge (i.e., retained on $425-\mu \mathrm{m}$ sieve) investigated in this study were analysed in order to investigate the sensitivity of the masses of the dried specimens and, hence, the values of water content. Oven-drying data for the sewage sludge fraction passing the $425-\mu \mathrm{m}$ sieve reported previously by O'Kelly (2004a, 2005b, $2005 \mathrm{c}$ ) are also considered in this analysis. Figure 5 shows the 
Drying temperature and water contentstrength correlations

O'Kelly

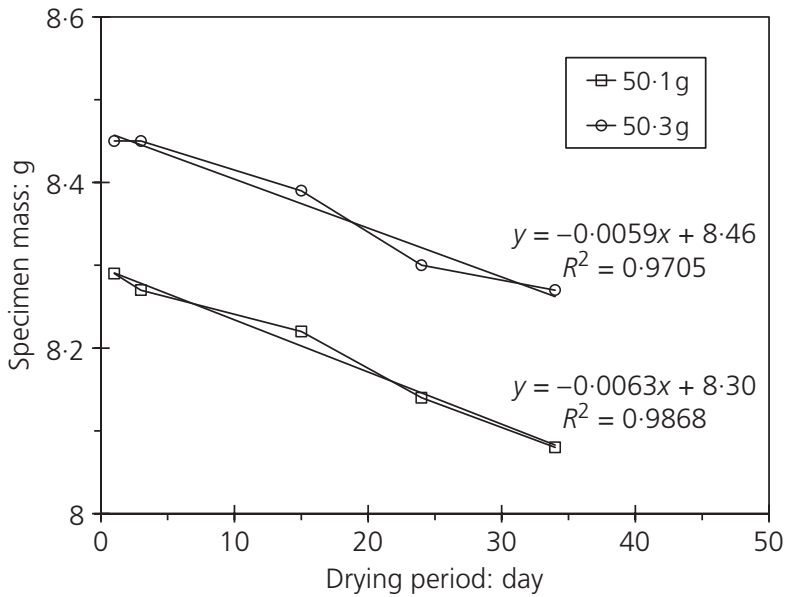

Figure 4. Drying at $105^{\circ} \mathrm{C}$ of WTR specimens having initial wet masses of nominally $50 \mathrm{~g}$ using a forced-draft oven ( $w=503 \%$, based on the 48-h specimen dry mass)

sensitivity of the specimen dry mass for the WTR material to oven temperature and drying period. These data are expressed in terms of the dimensionless parameter $\alpha$ and plotted against oven temperature in Figure 6(a,b), where $\alpha$ is the water content parameter (O'Kelly 2004a, 2005b), defined as:

$$
\alpha=\frac{m_{\mathrm{ref}}}{m_{t^{\circ} \mathrm{C}}}
$$

where $m_{\text {ref }}$ and $m_{t^{\circ} \mathrm{C}}$ are the specimen equilibrium dry masses corresponding to a reference oven temperature and lower temperature of $t^{\circ} \mathrm{C}$, respectively, with $\alpha_{105^{\circ} \mathrm{C}}$ and $\alpha_{110^{\circ} \mathrm{C}}$ referring

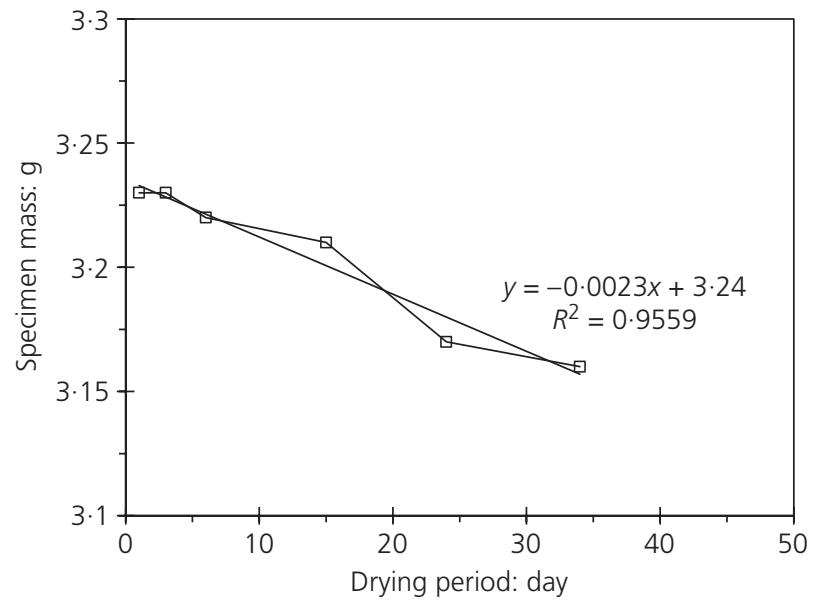

Supplementary Figure C. Drying at $105^{\circ} \mathrm{C}$ of WTR specimen having an initial wet mass of $20 \mathrm{~g}$ using a forced-draft oven ( $w=503 \%$, based on the 48-h specimen dry mass)

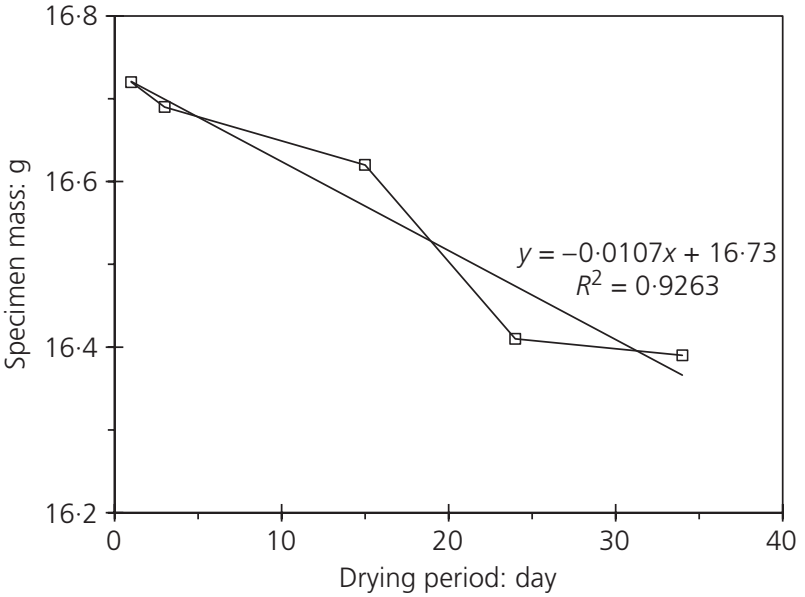

Supplementary Figure D. Drying at $105^{\circ} \mathrm{C}$ of WTR specimen having an initial wet mass of $100 \mathrm{~g}$ using a forced-draft oven ( $w=503 \%$, based on the 48-h specimen dry mass)

to reference temperatures of $105^{\circ} \mathrm{C}$ and $110^{\circ} \mathrm{C}$, respectively. For temperatures below the reference oven temperature, $\alpha \leq 1$, with a value of unity indicating an insensitive material for the temperature range considered. Parameter $\alpha$ is closely connected to Skempton and Petley's (1970) apparent moisture content (AMC) ratio by
1.

$$
\alpha=\frac{1}{1+\mathrm{AMC}}
$$

In the present investigation, the author chose to perform the analysis in terms of the $\alpha$ parameter since the raw experimental data were in terms of specimen dry mass, rather than water content. Figure 6(c)

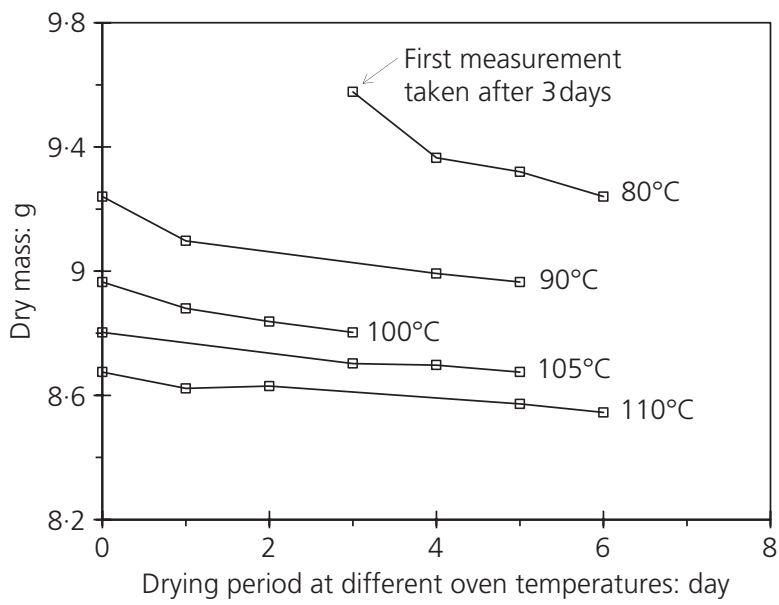

Figure 5. Reduction in dry specimen mass against drying period at different oven temperatures for the WTR material 
Drying temperature and water contentstrength correlations

O'Kelly

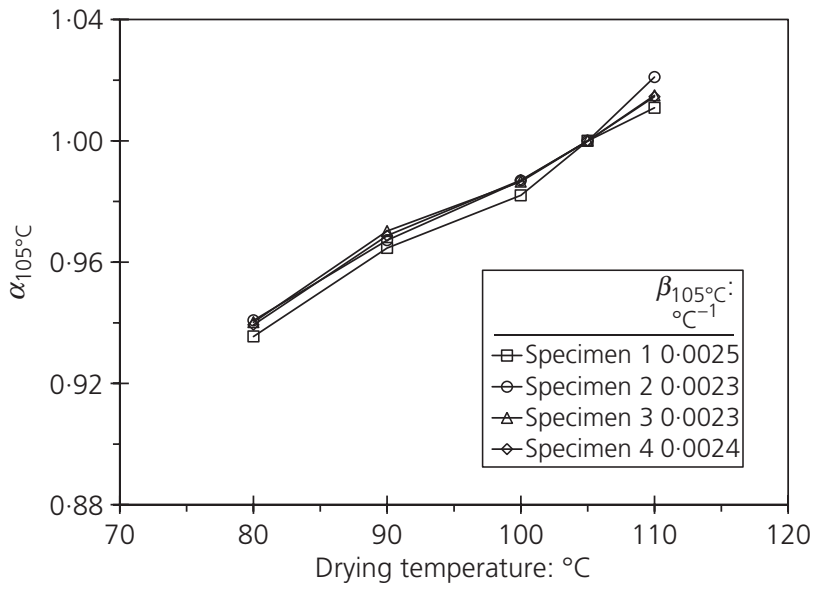

(a)

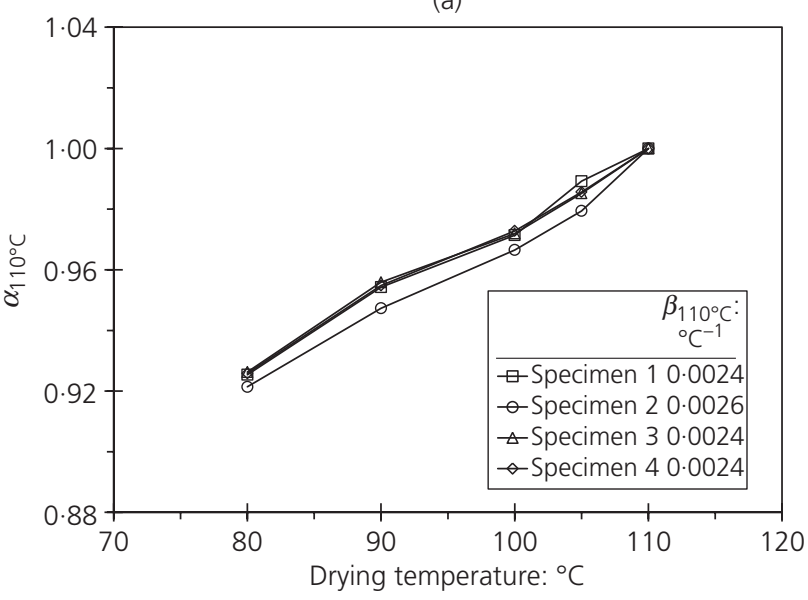

(b)

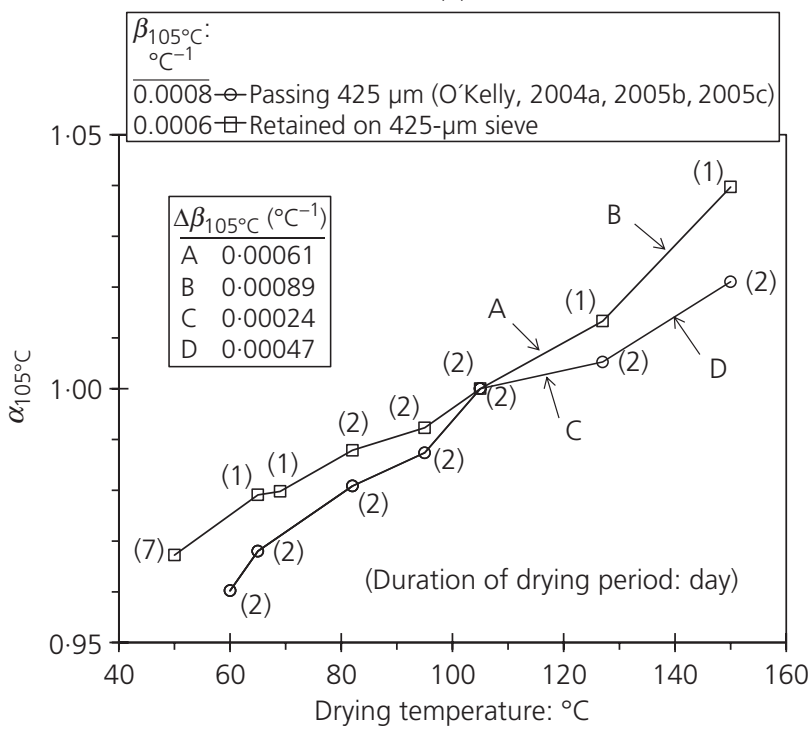

(c)

Figure 6. Water content parameter, $\alpha$, plotted against oven-drying temperature. Note: $\Delta \beta_{105^{\circ} \mathrm{C}}$ is the gradient for the temperature interval based on the specimen equilibrium dry mass at $105^{\circ} \mathrm{C}$. (a) $\alpha_{105^{\circ} \mathrm{C}}$ values for WTR. (b) $\alpha_{110^{\circ} \mathrm{C}}$ values for WTR. (c) $\alpha_{105^{\circ} \mathrm{C}}$ values for sewage sludge material. presents values of $\alpha_{105^{\circ} \mathrm{C}}$ plotted against drying temperature for the two fractions of the sewage sludge (i.e., passing and retained on the $425-\mu \mathrm{m}$ sieve), with the former determined from data reported by O’Kelly (2004a, 2005b, 2005c).

Table 1 presents a comparison of $\alpha$ values determined from experimental oven-drying data for 16 very different materials reported in literature. Comparing $\alpha$ values for $80^{\circ} \mathrm{C}$ and $85^{\circ} \mathrm{C}$, the coarse fraction of the sewage sludge material investigated in the present study (i.e., material retained on the $425-\mu \mathrm{m}$ sieve) and the 15 soils considered by Gilbert (1990), Skempton and Petley (1970) and O'Kelly (2005b), which included peats, clay, silt, sludge and mud having LOI values of 5.5-99\%, were all relatively insensitive to oven temperature $\left(\alpha_{105^{\circ} \mathrm{C}} \geq 0.97\right.$ for $80^{\circ} \mathrm{C}$ and $\left.85^{\circ} \mathrm{C}\right)$. However, the WTR material investigated in this study and the fibrous peat from the Mer Bleue Peat Bog near Ottawa considered by MacFarlane and Allen (1965) were more sensitive (corresponding $\alpha_{105^{\circ} \mathrm{C}}=0.92$ $0 \cdot 94$ ). This fibrous peat was reported as category 10 material (i.e., woody particles held in non-woody, fine fibrous peat) according to the Canadian peat classification system after Radforth (1969).

In general, close inspection of the drying curves presented in Figure 6 indicates that marginally steeper gradients occurred for the temperature range $80-90^{\circ} \mathrm{C}$. This behaviour has also been reported by O'Kelly $(2005$ b, 2005d) for various organic soils. MacFarlane and Allen (1965) and Hosang and Locker (1971) reported that this temperature range coincided with the commencement of charring of some organic matter in fibrous peats. Although not performed in the present investigation, future studies could employ chemistry analytical tools (e.g., gas chromatography/mass spectrometry analysis) on test specimens, both before and after oven drying at set temperatures in the range $80-110^{\circ} \mathrm{C}$, to investigate whether a loss of organic matter actually occurs and establish its magnitude.

The gradient $(\beta)$ of the parameter $\alpha$ against drying temperature trend lines were determined, with $\beta_{105^{\circ} \mathrm{C}}$ and $\beta_{110^{\circ} \mathrm{C}}$ denoting values for oven temperatures of $t \leq 105^{\circ} \mathrm{C}$ and $110^{\circ} \mathrm{C}$, respectively. For the sewage sludge fractions passing and retained on the $425-\mu \mathrm{m}$ sieve, the $\beta_{105^{\circ} \mathrm{C}}$ values were similar at $0 \cdot 0008^{\circ} \mathrm{C}^{-1}$ and $0 \cdot 0006^{\circ} \mathrm{C}^{-1}$, respectively, indicating relatively small but comparable levels of susceptibility under these elevated temperatures.

For the WTR material, the $\beta_{105^{\circ} \mathrm{C}}$ and $\beta_{110^{\circ} \mathrm{C}}$ values were significantly greater at $0.0024^{\circ} \mathrm{C}^{-1}$ and $0.0025^{\circ} \mathrm{C}^{-1}$, respectively. The masses of the dried specimens also showed no signs of reaching an equilibrium values by the end of the 34-day drying period at $105^{\circ} \mathrm{C}$ (Figure 4). However, these $\beta$ values are considerably below the $\beta_{105^{\circ} \mathrm{C}}$ value of $0.0037^{\circ} \mathrm{C}^{-1}$ determined for the fine fibrous peat studied by MacFarlane and Allen (1965). For the WTR material, the steady loss in dry specimen mass over the 34-day drying period did not occur on account of the Magnafloc additive, which only becomes unstable above $\sim 150^{\circ} \mathrm{C}$ (O'Kelly and Quille, 2009; O'Kelly, 2010). At only $\sim 3.5 \%$ of the dry solids mass, the amount of Magnafloc additive present could not, in any event, sustain the recorded rates of reduction in specimen mass shown in Figure 4. Instead, it is 
postulated that the steady and significant loss in mass of the dried WTR specimens was largely due to vaporisation of substances other than water, along with some charring and oxidation of susceptible organic solids.

Measured $\alpha_{105^{\circ} \mathrm{C}}$ values for higher oven temperatures of $127^{\circ} \mathrm{C}$ and $150^{\circ} \mathrm{C}$ are also presented in Figure $6(\mathrm{c})$ for the fractions of the sewage sludge material passing and retained on the $425-\mu \mathrm{m}$ sieve. Above $100^{\circ} \mathrm{C}$, reductions in equilibrium dry mass of an organic test specimen are caused by charring and oxidation of organic matter and (or) by vaporisation of substances other than water. Referring to the $\Delta \beta_{105^{\circ} \mathrm{C}}$ values reported in Figure 6(c) for the temperature intervals of $105-127^{\circ} \mathrm{C}$ and $127-150^{\circ} \mathrm{C}$, the sludge fraction retained on the $425-\mu \mathrm{m}$ sieve was approximately twice as susceptible, with the level of susceptibility also almost doubling in going from the lower to the higher temperature range interval. This reflects greater levels of charring and oxidation expected for coarse fibres at these elevated temperatures. Using Equation 2 and pertinent $\alpha_{105^{\circ} \mathrm{C}}$ values in Figure 6(c), compared with an oven-drying temperature of $105^{\circ} \mathrm{C}$, the difference in deduced values of water content for $60^{\circ} \mathrm{C}$ was 1.9 times greater than for $150^{\circ} \mathrm{C}$ in the case of material passing the $425-\mu \mathrm{m}$ sieve. This is supported by $\Delta \beta_{105^{\circ} \mathrm{C}} \approx 0.0008^{\circ} \mathrm{C}^{-1}$ for $t=60-105^{\circ} \mathrm{C}$ compared with values of $0.00024^{\circ} \mathrm{C}^{-1}$ and $0.00047^{\circ} \mathrm{C}^{-1}$ for $105-127^{\circ} \mathrm{C}$ and $127-150^{\circ} \mathrm{C}$, respectively. However, the opposite occurred for the sludge fraction retained on the $425-\mu \mathrm{m}$ sieve, with the difference in deduced water content values for $150^{\circ} \mathrm{C}$ approximately 1.6 times greater than for $60^{\circ} \mathrm{C}$.

In the triaxial compression tests, the undrained strength was determined as half of the peak deviatoric stress (see Figure 7), with a correction applied for the restraining effect of the rubber membrane enclosing the test specimen (BS1377-7; BSI, 1990c). These specimens all failed by general ductile bulging, with between $20 \%$ and $30 \%$ axial strain required to mobilise peak deviator stress, typical of organic soils.

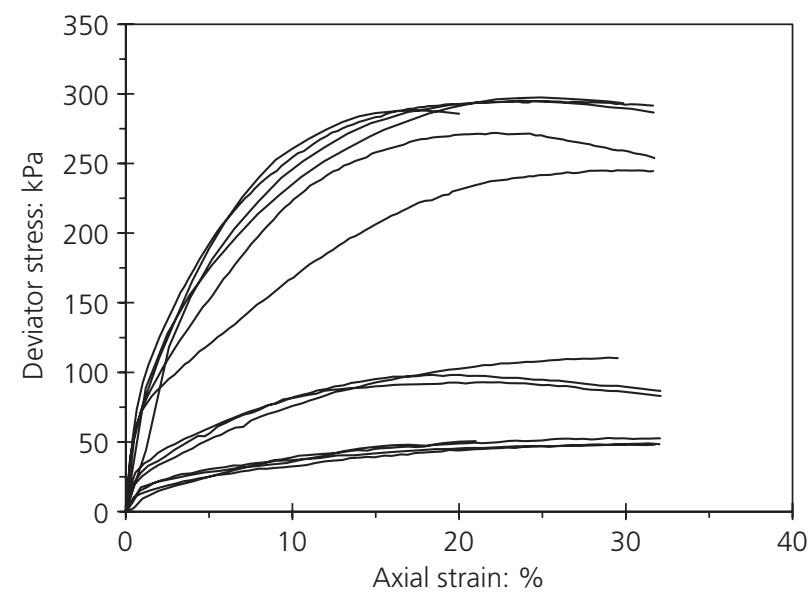

Figure 7. Undrained triaxial compression testing of WTR material prepared at different water contents

\section{Effect of oven temperature on water content-strength} correlations

Figure 8 presents data of fall-cone penetration depth and undrained strength plotted against measured values of water content for an oven-drying temperature of $105^{\circ} \mathrm{C}$, determined in accordance with BS1377-2 (BSI, 1990a). Undrained strength was deduced from the measured cone penetration depth using an experimentally derived cone factor value of $0 \cdot 60$, which produces a one-toone correspondence between fall-cone and triaxial compression strengths for this WTR material (O'Kelly, 2014). Also included in this figure are correlations derived using Equation 2 for water contents corresponding to oven-drying temperatures of $80^{\circ} \mathrm{C}$ and $110^{\circ} \mathrm{C}$, using appropriate experimental values of $\alpha_{105^{\circ} \mathrm{C}}$ from Figure 6 in these calculations.

\section{2. $w_{t^{\circ} \mathrm{C}}=\left[\alpha_{105^{\circ} \mathrm{C}}\left(w_{105^{\circ} \mathrm{C}}+1\right)\right]-1$}

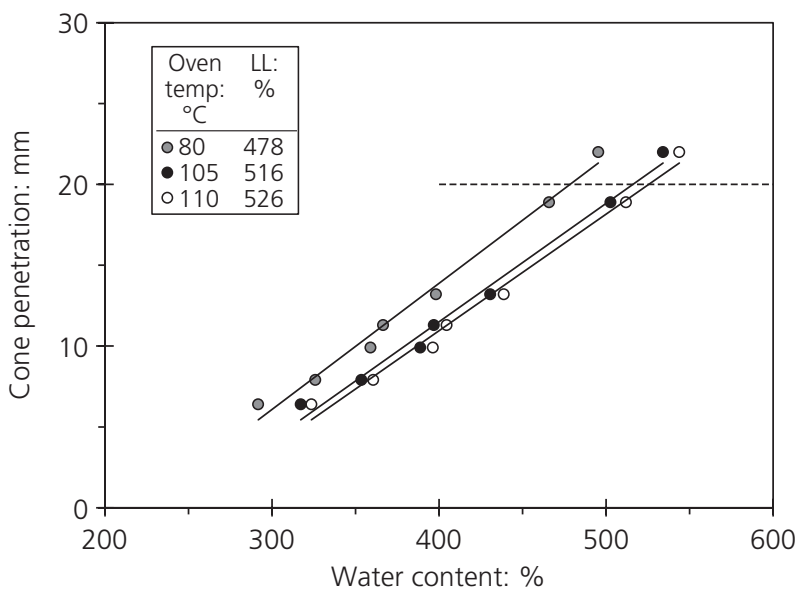

(a)

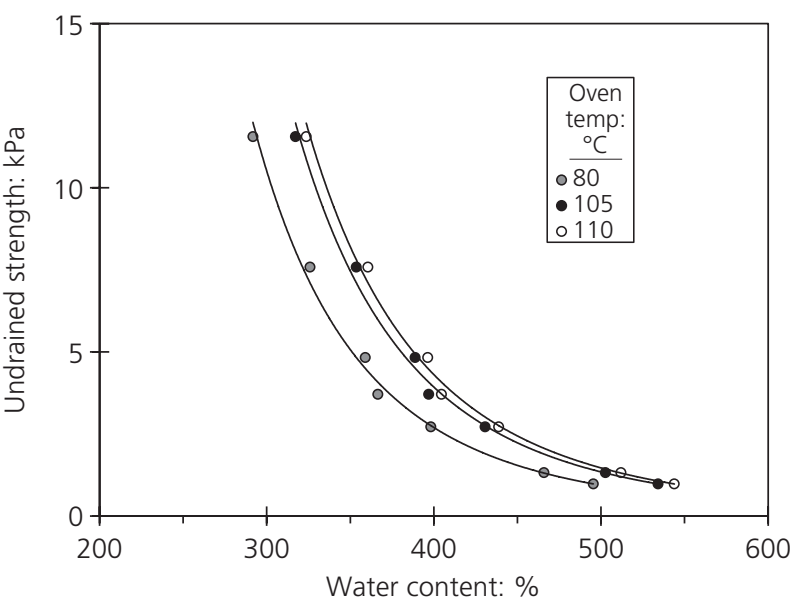

(b)

Figure 8. Fall cone-water content correlations for the WTR material demonstrating the significance of oven temperature. (a) Cone penetration depth. (b) Undrained strength. 
where $w_{105^{\circ} \mathrm{C}}$ and $w_{t}{ }^{\circ} \mathrm{C}$ are dimensionless values of water content (i.e., not $\%$ ) measured for an oven-drying temperature of $105^{\circ} \mathrm{C}$ and deduced for a lower temperature of $t^{\circ} \mathrm{C}$, respectively; $\alpha_{105^{\circ} \mathrm{C}}$ is the measured specimen equilibrium dry mass for an oven temperature of $105^{\circ} \mathrm{C}$ divided by the corresponding mass for the lower temperature of $t^{\circ} \mathrm{C}$. Refer to O'Kelly (2004a, 2005b) for further details.

The liquid limit (LL) corresponds to the water content value at the state transition between the liquid and plastic states. The British standard fall-cone LL value is defined by a $20-\mathrm{mm}$ penetration depth for a smooth $80 \mathrm{~g}-30^{\circ}$ cone that is allowed to free fall from an at-rest position, with the cone tip initially just contacting the surface of the test specimen (BS1377-2; BSI, 1990a). Referring to Figure 8(a), for the WTR material an absolute difference of 48 percentage occurred between deduced LL values for oven-drying temperatures of $80^{\circ} \mathrm{C}$ and $110^{\circ} \mathrm{C}$, resulting in the $\mathrm{LL}$ value for $80^{\circ} \mathrm{C}$ being $9 \cdot 1 \%$ below that for $110^{\circ} \mathrm{C}$. This is considered excessive, even though these LL values were extremely high, with deduced values increasing from $478 \%$ to $526 \%$ with increasing temperature from $80^{\circ} \mathrm{C}$ to $110^{\circ} \mathrm{C}$. However, for oven-drying temperatures of $105^{\circ} \mathrm{C}$ and $110^{\circ} \mathrm{C}$, the maximum difference between measured and deduced LL values, respectively, was only 10 percentage; that is, the $\mathrm{LL}$ value for $110^{\circ} \mathrm{C}$ was 1.9 greater than that for $105^{\circ} \mathrm{C}$.

Figure 9 presents data of saturated remoulded undrained shear strength $\left(s_{\mathrm{ur}}\right)$ for the WTR material determined from the miniature vane and triaxial compression testing. The reported data are for freshly remoulded material since the WTR was thixotropic (O'Kelly, 2010, 2014; O'Kelly and Quille, 2010). Although, in practice, one is usually more interested in the dependency of undrained strength on water content (as shown in Supplementary Figure E), their relationship is presented in the empirical form given by Equation 3 for further consideration, since the values of coefficients $a$ and

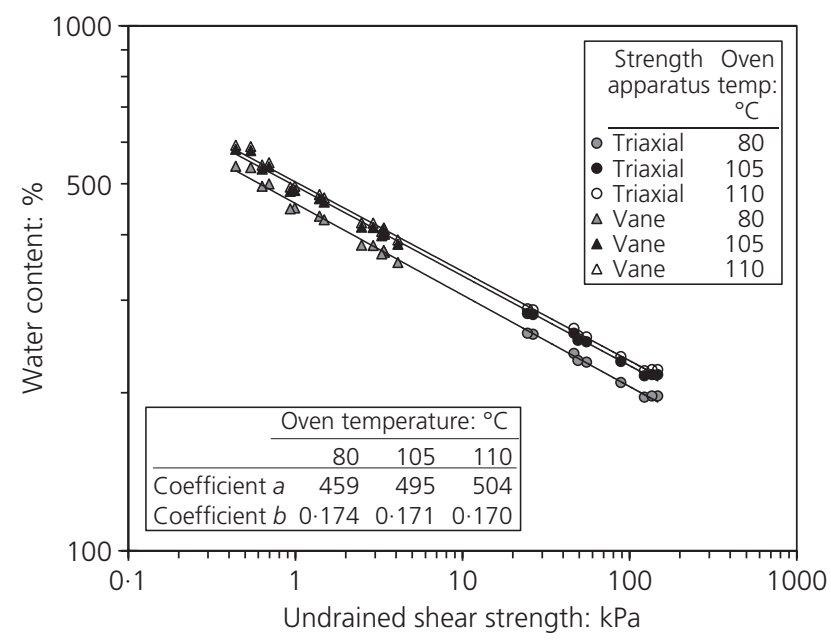

Figure 9. Bi-logarithmic water content-undrained strength correlations for WTR material, with water content determined for different oven-drying temperatures

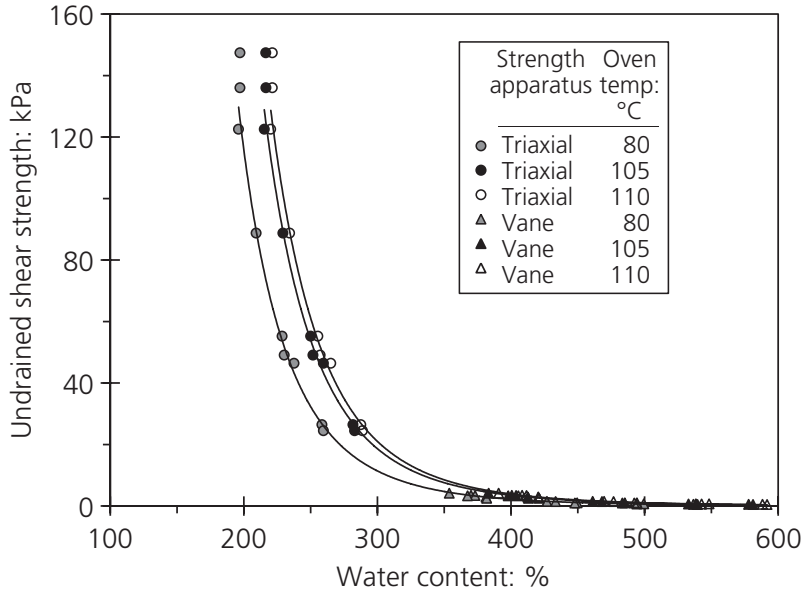

Supplementary Figure E. Water content-undrained strength relationships for WTR material dried at different oven temperatures

$b$ are closely related to geotechnical properties. Coefficient $b$ relates to the soil compressibility and for mineral soils is equal in value to the gradient of the isotropic compression line (refer to Koumoto and Houlsby, 2001). The $\log w-\log S_{\text {ur }}$ relationship for the WTR material was found to be strongly linear over the wide range of water content values considered, extending well beyond the measured plastic range, with coefficient of determination $\left(R^{2}\right)$ values very close to unity. Figure 9 also includes correlations for water contents corresponding to oven-drying temperatures of $80^{\circ} \mathrm{C}$ and $110^{\circ} \mathrm{C}$. These were deduced from the measured water content values for an oven temperature of $105^{\circ} \mathrm{C}$ using Equation 2 and appropriate experimental values of $\alpha_{105^{\circ} \mathrm{C}}$ from Figure 6(a). The values of coefficients $a$ and $b$ reported for the different oven temperatures in Figure 9 were determined from regression analysis of the experimental $\log w-\log S_{\text {ur }}$ data. For the WTR material, the deduced $w-S_{\text {ur }}$ correlation for $80^{\circ} \mathrm{C}$ was significantly different from that for $105^{\circ} \mathrm{C}$ and $110^{\circ} \mathrm{C}$, with the value of coefficient $a$ more sensitive to oven-drying temperature (Figure 9). Hence an important finding is that, in specifying a strength requirement, a value of oven-drying temperature must also be given in instances where water content correlations are indirectly used to assess strength. For instance, the target minimum $s_{\text {ur }}$ value of $25 \mathrm{kPa}$ recommended from a geotechnical standpoint by Siedlungsabfall (1993) for co-disposal of high water content materials at municipal landfills would require, in the case of the WTR material, maximum values of water content of $262 \%, 285 \%$ and $292 \%$ based on ovendrying temperatures of $80^{\circ} \mathrm{C}, 105^{\circ} \mathrm{C}$ and $110^{\circ} \mathrm{C}$, respectively. The same combination of strength and oven temperature values must be consistently adopted throughout the assessment and verification process for disposal of material to landfill; otherwise, interpolated

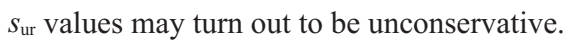

3. $w=a s_{\mathrm{ur}}^{-b}$ 
where coefficient $a$ is the value of water content (as \%) corresponding to $s_{\mathrm{ur}}=1 \mathrm{kPa}$ and; coefficient $b$ is the gradient of the $\log w-\log S_{\text {ur }}$ correlation. Refer to Koumoto and Houlsby (2001) and O'Kelly (2013a, 2014) for further details.

Conceivably, using liquidity index instead of water content might sort out differences induced by drying temperature, considering that, for a given material, the values of LL (see Figure 8(a)) and plastic limit (PL) will be reduced proportionately. Figure 10 shows that this is the case for the WTR material, with minor differences in the equations for the best-fit trend lines arising on account of rounding errors. Again, the coefficient of determination $\left(R^{2}\right)$ values were very close to unity, indicating very strong correlations. In the calculations, $\mathrm{PL}$ values corresponding to oven-drying temperatures of $80^{\circ} \mathrm{C}$ and $110^{\circ} \mathrm{C}$ were determined from the PL value of $268 \%$ measured using the Casagrande thread-rolling method and for an oven temperature of $105^{\circ} \mathrm{C}$ (BS1377-2; BSI, 1990a). The modified liquidity index ( $I_{\mathrm{LN}}$, Equation 4) after Kuomoto and Houlsby (2001) has been introduced, given the bi-logarithmic relationship existing between water content and undrained strength for these high or extremely high water content materials (see Figure 9). This relationship has been investigated experimentally and reported valid over the full plastic range for amorphous organic (O'Kelly, 2014; Zentar et al., 2009) and fine-grained mineral soils (Koumoto and Houlsby, 2001; Sharma and Bora, 2003). Figure 10 indicates that this is also the case for the WTR material under investigation. Note that $I_{\mathrm{LN}}$ values of unity and 0 correspond to the LL and PL states respectively. This approach, which usually produces a quite sharp correlation for a given material, is examined in greater detail in the Discussion section which follows.

4. $I_{\mathrm{LN}}=\frac{\log w-\log \mathrm{PL}}{\log \mathrm{LL}-\log \mathrm{PL}}$

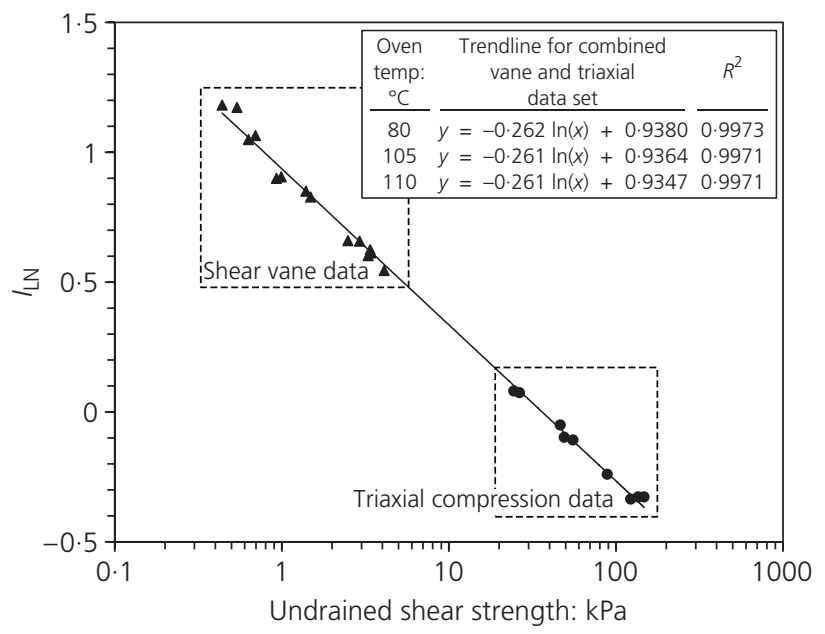

Figure 10. Coincidence of modified liquidity index-undrained strength correlations for WTR material dried at different oven temperatures for water content determinations

\section{Discussion}

\section{Oven-drying temperature}

Conflicting views are reported in the literature regarding an appropriate oven-drying temperature for water content determinations on organic soils. Many researchers have recommended using lower oven temperatures in the range $60-90^{\circ} \mathrm{C}$ to prevent charring and oxidation of susceptible organic matter. For instance, in the case of fibrous peat, MacFarlane and Allen (1965) reported that oven drying for water content determinations should never be performed at temperatures greater than $95^{\circ} \mathrm{C}$ and, preferably, should not exceed $85^{\circ} \mathrm{C}$, in order to ensure that volatile substances other than water are not improperly removed. Other drying temperatures including $60^{\circ} \mathrm{C}$ (Marachi et al., 1983; Miyakawa, 1959; O'Kelly, 2005a, 2006), 60-70 ${ }^{\circ} \mathrm{C}(\mathrm{Ng}$ and Eischens, 1983), $75-80^{\circ} \mathrm{C}$ (Hosang and Locker, 1971), $80^{\circ} \mathrm{C}$ (Boylan and Long, 2010), 85 ${ }^{\circ} \mathrm{C}$ (Goodman and Lee, 1962) and $90^{\circ} \mathrm{C}$ (Landva et al., 1983; Riley, 1989) have also been reported. Oven-drying temperatures in the range $60-90^{\circ} \mathrm{C}$ are still routinely used in some commercial and research laboratories for water content determinations on organic soils. For instance, the ASTM standard test method for water content determinations on soil and rock (ASTM D2216; ASTM, 2010) states that, for fibrous peat and other highly organic soils, it may be desirable to use a lower ovendrying temperature of $60^{\circ} \mathrm{C}$ or, alternatively, use desiccators at ambient laboratory temperature. However, since the specimen dry mass is a function of oven temperature, water contents determined in these studies will be lower than values determined for the drying temperature range $100-110^{\circ} \mathrm{C}$ on account of reduced potential for charring and oxidation of susceptible organic matter, but also because significant amounts of residual pore water can remain within the test specimen (O'Kelly, 2004a, 2005b, 2005c, 2005d). Hence, what is potentially lost by this inconsistency in oven temperature values adopted is the ability to meaningfully compare reported values of water content, especially for sensitive materials. Another consideration is that the drying period necessary to achieve equilibrium dry mass increases for lower oven temperatures, with large or very wet test specimens requiring even longer periods for the specimen mass to equilibrate. For instance, in the case of peat, about 2 days are required to achieve an equilibrium state for oven drying at $80-85^{\circ} \mathrm{C}$ (MacFarlane and Allen, 1965), compared with at least 3 days for $60^{\circ} \mathrm{C}$ (Gilbert, 1990).

On the other hand, a few researchers have definitively reported that oven drying of organic soils at between $100^{\circ} \mathrm{C}$ and $110^{\circ} \mathrm{C}$ is acceptable for routine water content determinations. In particular, Skempton and Petley (1970) and Hobbs (1986) reported that oven drying of organic clay, clayey peat and peat (including fibrous material) at $105^{\circ} \mathrm{C}$ or $110^{\circ} \mathrm{C}$ is acceptable for routine water content determinations. More recently, the US EPA (2001) standard method for the determination of total solids specifies oven drying over the temperature range $103-105^{\circ} \mathrm{C}$ for a minimum 12 -h period. This standard covers such solid and semisolid samples as soils, sediments, municipal sewage sludge, sludge separated from water and wastewater treatment processes and sludge cakes from vacuum 
Drying temperature and water content-

strength correlations

O'Kelly filtration, centrifugation or other sludge dewatering processes. An oven temperature of $105 \pm 5^{\circ} \mathrm{C}$ is specified by the ASTM standard test method for water content determinations on peat and other organic soils (ASTM 2007: D2974-07a). This could be seen as conflicting with specific recommendations given by ASTM D2216 (ASTM, 2010) in relation to water content determination on fibrous peat and other highly organic soils, which states that a lower oven temperature of $60^{\circ} \mathrm{C}$ may be desirable for these materials. However, for the fraction of the sewage sludge material passing the $425-\mu \mathrm{m}$ sieve, O'Kelly $(2004 \mathrm{a}, 2005 \mathrm{c})$ reported that the determination of water content values on the basis of an oven-drying temperature of $60^{\circ} \mathrm{C}$, instead of $105 \pm 5^{\circ} \mathrm{C}$, introduced a larger error on account of significant amounts of residual pore water remaining in the dried test specimen. With water content defined as the mass ratio of the pore water to solids, O'Kelly (2004a, 2005c) identified that, for materials sensitive to oven temperature, the true value of water content is determined for the oven-drying temperature at which the mass of residual pore water remaining within the test specimen exactly balances the loss in solids mass occurring on account of charring and oxidation of organic matter and (or) vaporisation of substances other than water. In other words, even though the material may be sensitive to oven temperature, at this particular temperature value, the mass of the dried specimen equals the mass of solids in the wet specimen. An experimental technique developed to establish this material-specific oven-drying temperature was also presented by the author. In the case of the fraction of the sewage sludge passing the $425-\mu \mathrm{m}$ sieve, it was established that the true water content is determined for an oven-drying temperature of $86^{\circ} \mathrm{C}$, and, furthermore, when compared against this oven temperature, a larger error in water content values arose for oven drying at $60^{\circ} \mathrm{C}$ compared with the standard drying temperature ranges of $105-$ $110^{\circ} \mathrm{C}$ (BS1377-2; BSI, 1990a) and $105 \pm 5^{\circ} \mathrm{C}$ (ASTM D2974; ASTM, 2007) specified for mineral soils. It is also more expedient to perform water content determinations using these standard temperature ranges, rather than at lower oven temperatures in the range $60-90^{\circ} \mathrm{C}$ adopted in some literature, given that the drying period required to achieve equilibrium dry mass can increase significantly with reducing temperature.

The sensitivity of the dried specimen mass to oven temperature will generally not be apparent from visual observation (either with the naked eye or via microscopic examination) of the material in the test specimen or from the soil description. For instance, referring to Table 1, fibrous peats having similar LOI values of $96.8 \%$ and $99 \%$ may be sensitive or relatively insensitive (MacFarlane and Allen (1965) and Skempton and Petley (1970) studies, respectively) to an increase in oven temperature. For example, $\alpha_{105^{\circ} \mathrm{C}}$ values of 0.932 and 0.988 corresponding to the increase in oven temperature from $85^{\circ} \mathrm{C}$ to $105^{\circ} \mathrm{C}$ were deduced from reported data in the respective studies. The definitive way of determining the level of sensitivity is by measuring the reduction in mass of the dried specimen for a series of step increases in oven temperature, as was performed in the present investigation, although this approach is time consuming and the results are material specific.

\section{Water content-strength correlations}

Potentially greater amounts of charring and oxidation of organic matter and (or) vaporisation of substances other than water may be expected to occur for more sensitive materials at higher oven temperatures, such as the WTR material investigated in the present study. One major consequence of different researchers and commercial laboratories using different oven-drying temperatures for water content determinations on such materials is to produce greater disparity in interpolated index values and also in experimental correlations between water content and other engineering properties, with specific examples presented earlier in this paper (e.g., see Figures 8 and 9).

Differences in the $\log w-\log S_{\text {ur }}$ correlation for the same WTR material arising from different oven-drying temperatures were found to be resolved by plotting the modified liquidity index instead of water content. Hence, if different researchers and (or) commercial laboratories consistently measure values of LL and PL using the same test methods and standardised procedures, but along with water content, these Atterberg limit values are based on different oven-drying temperatures, then the values of liquidity index will nevertheless bear a one-to-one correspondence. It is now widely accepted that strength values measured at the LL and PL states identified using the Casagrande percussion-cup and thread-rolling methods are not unique (see Barnes and O'Kelly, 2011; Haigh, 2012; Haigh et al., 2013). Hence, although usually quite sharp for a given material, $I_{\mathrm{LN}}-\log s_{\mathrm{ur}}$ correlations can vary widely between materials. In particular, for organic sediments, the saturated remoulded undrained strengths at LL and PL $\left(s_{\mathrm{ur}(\mathrm{LL})}\right.$ and $s_{\mathrm{ur}_{(\mathrm{PL})}}$, respectively) are often substantially below respective values of approximately 1.7 and $170 \mathrm{kPa}$ often considered typical of many fine-grained mineral soils (Sharma and Bora, 2003). For instance, referring to Figures 9 or 10 and reported Atterberg limit values in Table $1, s_{\mathrm{ur}_{(\mathrm{LL})}}=0.78 \mathrm{kPa}$ and $s_{\mathrm{ur}_{(\mathrm{PL})}}=36 \mathrm{kPa}$ for the WTR material considered in the present study. A range of $s_{\mathrm{ur}_{(\mathrm{PL})}}=9-26 \mathrm{kPa}$ (mean of $17 \mathrm{kPa}$ ) was reported by Zentar et al. (2009) for four dredged sediments having organic contents of 6·7-9·7\%. O'Kelly (2014) and Zhang and O'Kelly (2014) have also shown that, for WTR material and amorphous peat, PL values determined by the Casagrande thread-rolling method are notional in that the bulk materials can still be remoulded at lower values of water content. Hence O'Kelly (2014) concluded that the use of liquidity index as an indicator of the consistency of these materials is unreliable in practice. It can also be argued that the LL and PL conditions are defined for fine-grained mineral soils, with specific physical meaning, and that these Atterberg limits should not be applied to organic soils (O'Kelly, 2014). For fibrous materials including sewage sludge and fibrous peat, it is often not possible to perform the PL test, in that uniform soil threads cannot be rolled out to $3 \mathrm{~mm}$ in diameter on account of scale effects related to the coarse fibrous particles and hence these materials are reported as non-plastic (O'Kelly and Zhang, 2013; Pichan and O'Kelly, 2013; Zhang and O'Kelly, 2014). However, in practice, the bulk materials are readily remoulded over a certain range of water content and therefore they are plastic. Another consideration is that, for 
gelatinous soils (e.g., sewage sludge), the $I_{\mathrm{LN}}-\log s_{\mathrm{ur}}$ relationship is affected by the viscous (gel-like) pore fluid particularly for materials of very soft and slurry consistencies, in which case this relationship becomes non-linear (O'Kelly, 2013b). Hence, in view of all of the above, the take-home message is that the $I_{\mathrm{LN}}-\log S_{\text {ur }}$ approach is not particularly useful in practice.

Reviews by Geuzens and Dieltjens (1991) and O'Kelly and Quille (2010) of reported $w-S_{\text {ur }}$ data for municipal sludge and residue materials have highlighted the wide scatter, which was mainly attributed to material heterogeneity. However, from experimental observations for the WTR material in the present study, it is probable that a significant amount of the scatter occurring for some materials reported in the literature may actually be attributable to differences in oven-drying temperatures routinely used by different researchers for water content determinations, from as low as $35^{\circ} \mathrm{C}$ (Raghu and Hsieh, 1986) up to the standardised values of 105 $110^{\circ} \mathrm{C}$ and $105 \pm 5^{\circ} \mathrm{C}$ used for oven drying of mineral soils.

\section{Recommendations}

The author is of the view that routine water content determinations on organic sludge and residue materials should be performed using a standardised oven temperature and drying period. Apart from gypsum and some tropical clays identified by Head (1997), which are very sensitive to temperatures greater than $90^{\circ} \mathrm{C}$ (i.e., water of crystallisation is removed), the author recommends that this standardised drying temperature should be the same as that used for water content determinations on mineral soils, that is, $105-110^{\circ} \mathrm{C}$ (BS1377-2; BSI, 1990a) or $105 \pm 5^{\circ} \mathrm{C}$ (ASTM D2974; ASTM, 2007). A direct benefit is that this would avoid the requirement for separate ovens, set at different temperatures, for drying of mineral and organic soils. This recommendation is consistent with the US EPA (2001) and ASTM (ASTM 2007: D2974-07a) standard test methods and also with the findings of Skempton and Petley (1970) and Hobbs (1986) for water content determinations on peats and other organic soils. Over these temperature ranges, all of the pore water is evaporated from the test specimen, usually within a 24-h period, whereas this can take considerably longer to achieve for lower oven temperatures. For some sensitive materials such as the WTR material, a steady reduction in mass of the dried specimen may continue to occur for oven drying performed over an extended period of several weeks (see Figure 4). For these reasons, the writer also recommends a standardised drying period of $24 \mathrm{~h}$.

In cases where lower drying temperatures have been used, it is recommended that values of water content corresponding to these standardised oven temperatures be deduced from the measured water content values. In this regard, O'Kelly (2004a, 2005b) presented two methods to relate and standardise water content values determined for the same material but on the basis of different oven-drying temperatures. Furthermore, considering the very or extremely high water content (low dry unit weight) of municipal sludges and residues, the author also suggests using a minimum wet specimen mass of $50 \mathrm{~g}$ in performing water content determinations. With water contents in the range $215-600 \%$ (Figure 9), a WTR specimen of $50 \mathrm{~g}$ wet mass would have a corresponding dry mass of between $7 \cdot 1$ and $16 \cdot 7 \mathrm{~g}$, which is considered acceptable for water content determinations.

\section{Summary and conclusions}

The remoulded undrained strength-water content relationship depends on material characteristics, physical state and method of strength measurement. For reproducible water content determinations, the oven temperature and drying period are of great importance, influencing the measurement result since different physical states are produced. For example, in the case of the WTR material studied, oven-drying temperatures of $80^{\circ} \mathrm{C}$ and $110^{\circ} \mathrm{C}$ were found to produce significantly different water content-strength correlations. Since the use of a standardised oven temperature is desirable when correlating water content with strength and other engineering properties, it is recommended that oven drying of organic sludges and residues for water content determinations be performed over the temperature ranges of $105-110^{\circ} \mathrm{C}$ or $105 \pm 5^{\circ} \mathrm{C}$, in line with standardised ranges for mineral soils. For these temperature ranges, drying over a 24-h period in gravity-convection or forced-draft ovens achieves the same effect. Although some (very) minor charring and oxidation of organic matter and (or) vaporisation of substances other than water may occur for sensitive soils, these temperature ranges ensure full evaporation of the pore water, invariably within a 24-h period, compared with significantly longer drying periods required to achieve equilibrium mass for lower oven temperatures of $35-90^{\circ} \mathrm{C}$ adopted by some researchers. Even then, residual pore water remaining within the test specimen may introduce a larger error in the measured value of water content, compared with that potentially caused by some charring, oxidation and (or) vaporisation of substances other than water for higher oven temperatures. Future studies could employ chemistry analytical tools on test specimens, both before and after oven drying at temperatures in the range $80-110^{\circ} \mathrm{C}$, to investigate whether a loss of organic matter actually occurs and establish its extent. Another benefit of the standardisation of oven temperature is that mineral and organic test-specimens could then be dried together in the same oven, rather than requiring separate ovens set at different temperatures. The suggested minimum wet specimen mass for water content determinations on these high water content materials is $50 \mathrm{~g}$. Although the $I_{\mathrm{LN}}-\log s_{\text {ur }}$ correlation was found to be independent of oven-drying temperature, this approach is of limited value in practice since these correlations are material specific, along with general difficulties in measuring and interpreting Atterberg consistency limit values for organic soils.

\section{Acknowledgements}

The author thanks Eoin Dunne and Martin Carney, Department of Civil, Structural and Environmental Engineering, Trinity College Dublin, for performing the oven-drying and geotechnical tests reported in this paper. The author also thanks the reviewers for many helpful comments. 
Drying temperature and water content-

strength correlations

O'Kelly

\section{REFERENCES}

ASTM (2007) Standard Test Methods for Moisture, Ash, and Organic Matter of Peat and Other Organic Soils, D2974-07a. ASTM International, West Conshohocken, PA, USA.

ASTM (2008) Standard Test Method for Laboratory Determination of the Fiber Content of Peat Samples by Dry Mass, D1997-91. ASTM International, West Conshohocken, PA, USA.

ASTM (2010) Standard Test Methods for Laboratory Determination of Water (Moisture) Content of Soil and Rock by Mass, D2216-10. ASTM International, West Conshohocken, PA, USA.

Barnes GE and O'Kelly BC (2011) Discussion: An apparatus for the plastic limit and workability of soils. Proceedings of the ICE, Geotechnical Engineering 164(4): 293-294.

Boylan N and Long MM (2010) An investigation of two peat slope failures in the Wicklow mountains. Biology and Environment: Proceedings of the Royal Irish Academy 110B(3): 173-184.

BSI (1990a) Methods of Test for Soils for Civil Engineering Purposes (Classification Tests), BS1377: Part 2. British Standards Institution, Milton Keynes, UK.

BSI (1990b) Methods of Test for Soils for Civil Engineering Purposes (Chemical and Electro-chemical Tests), BS1377: Part 3. British Standards Institution, Milton Keynes, UK.

BSI (1990c) Methods of Test for Soils for Civil Engineering Purposes (Shear Strength Tests: Total Stress), BS1377: Part 7. British Standards Institution, Milton Keynes, UK.

Geuzens P and Dieltjens W (1991) Mechanical strength determination of cohesive sludges: a Belgian research project on sludge consistency. In Recent Developments in Sewage Sludge Processing (Colin F, Newman PJ and Puolanne YJ (eds.)). Elsevier, London, pp. 14-23.

Gilbert PA (1990) Computer-Controlled Microwave Drying of Potentially Difficult Organic and Inorganic Soils. U.S. Army Engineer Waterways Experiment Station, Technical Report GL-90-26. U.S. Army Corps of Engineers, Vicksburg, MS, USA.

Goodman LJ and Lee CN (1962) Laboratory and field data on engineering characteristics of some peat soils. In Proceedings of the Eighth Muskeg Research Conference (MacFarlane IC (ed.)). National Research Council of Canada, Saskatoon, Canada. Ottawa Technical Memorandum 74, pp. 107-129.

Haigh SK (2012) Mechanics of the Casagrande liquid limit test. Canadian Geotechnical Journal 49(9): 1015-1023.

Haigh SK, Vardanega PJ and Bolton MD (2013) The plastic limit of clays. Géotechnique 63(6): 435-440.

Head KH (1997) Manual of Soil Laboratory Testing. Volume 1: Soil Classification and Compaction Tests, 2nd edn. Pentech Press, London.

Hobbs NB (1986) Mire morphology and the properties and behaviour of some British and foreign peats. Quarterly Journal of Engineering Geology 19(1): 7-80.

Hosang JR and Locker JG (1971) Discussion: Ignition loss and other properties of peats and clays from Avonmouth, King's Lynn and Cranberry Moss. Géotechnique 21(4): 416-418.
Koumoto T and Houlsby GT (2001) Theory and practice of the fall cone test. Géotechnique 51(8): 701-712.

Landva AO, Korpijaakko EO and Pheeney PE (1983) Geotechnical classification of peats and organic soils. In Testing of Peats and Organic Soils, ASTM STP 820 (Jarrett PM (ed.)). American Society for Testing and Materials, pp. 37-51.

MacFarlane IC and Allen CM (1965) An Examination of Some Index Test Procedures for Peat. Internal Report No. 314. Division of Building Research, National Research Council Canada.

Marachi ND, Dayton DJ and Dare CT (1983) Geotechnical properties of peat in San Joaquin Delta. In Testing of Peats and Organic Soils. ASTM STP 820 (Jarrett PM (ed.)). American Society for Testing and Materials, pp. 207-217.

Mitchell JK (1993) Fundamentals of Soil Behavior, 2nd ed. Wiley, New York.

Miyakawa I (1959) Soil Engineering Research on Peaty Alluvia. Reports 1-3. Bulletin 20. Civil Engineering Research Institute, Hokkaido Development Bureau, Japan.

Ng SY and Eischens GR (1983) Repeated short-term consolidation of peats. In Testing of Peats and Organic Soils. ASTM STP 820 (Jarrett PM (ed.)). American Society for Testing and Materials, pp. 192-206.

Novak JT and Calkins DC (1975) Sludge dewatering and its physical properties. Journal of the American Water Works Association 67(1): 42-45.

O'Kelly BC (2004a) Accurate determination of moisture content of organic soils using the oven drying method. Drying Technology 22(7): 1767-1776, http://dx.doi.org/10.1081/DRT-200025642.

O'Kelly BC (2004b) Geotechnical aspects of sewage sludge monofills. Proceedings of the ICE, Municipal Engineer 157(3): 193-197.

O'Kelly BC (2005a) Consolidation properties of a dewatered municipal sewage sludge. Canadian Geotechnical Journal 42(5): 1350-1358, http://dx.doi.org/10.1139/t05-054.

O'Kelly BC (2005b) Method to compare water content values determined on the basis of different oven drying temperatures. Géotechnique 55(4): 329-332, http://dx.doi.org/10.1680/ geot.2005.55.4.329.

O'Kelly BC (2005c) New method to determine the true water content of organic soils. ASTM Geotechnical Testing Journal 28(4): 365-369, http://dx.doi.org/10.1520/GTJ11963.

O'Kelly BC (2005d) Oven-drying characteristics of soils of different origins. Drying Technology 23(5): 1141-1149, http://dx.doi.org/10.1081/DRT-200059149.

O'Kelly BC (2006) Geotechnical properties of municipal sewage sludge. Geotechnical and Geological Engineering 24(4): $833-$ 850, http://dx.doi.org/10.1007/s10706-005-6611-8.

O'Kelly BC (2008a) Effect of biodegradation on the consolidation properties of a dewatered municipal sewage sludge. Waste Management 28(8): 1395-1405, http://dx.doi.org/10.1016/j. wasman.2007.08.004.

O'Kelly BC (2008b) Geotechnical properties of a municipal water treatment sludge incorporating a coagulant. Canadian Geotechnical Journal 45(5): 715-725, http://dx.doi. org/10.1139/T07-109. 
O'Kelly BC (2010) Landfill disposal of alum water treatment residues: some pertinent geoengineering properties. Residuals Science and Technology 7(2): 95-113.

O'Kelly BC (2014) Characterisation and undrained strength of amorphous clay, Proceedings of the ICE, Geotechnical Engineering 167, http://dx.doi.org/10.1680/geng.11.00025. E-publication ahead of print.

O'Kelly BC (2013a) Discussion of "Enhancement of the shear strength of wastewater residuals using industrial waste by-products" by C. Kayser, T. Larkin and N. Singhal. ASCE Journal of Environmental Engineering 139(2): 312-315, http://dx.doi.org/10.1061/(ASCE)EE.1943-7870.0000608.

O'Kelly BC (2013b) Undrained shear strength-water content relationship for sewage sludge. Proceedings of the ICE, Geotechnical Engineering 166(6), http://dx.doi.org/10.1680/ geng.11.00016. E-publication ahead of print.

O'Kelly BC and Quille ME (2009) Compressibility and consolidation of water treatment residues. Proceedings of the ICE, Waste and Resource Management 162(2): 85-97, http:// dx.doi.org/10.1680/warm.2009.162.2.85.

O'Kelly BC and Quille ME (2010) Shear strength properties of water treatment residues. Proceedings of the ICE, Geotechnical Engineering 163(1): 23-35, http://dx.doi. org/10.1680/geng.2010.163.1.23.

O'Kelly BC and Zhang L (2013) Consolidated-drained triaxial compression testing of peat. ASTM Geotechnical Testing Journal 36(3): 310-321, http://dx.doi.org/10.1520/ GTJ20120053.

Pichan SP and O'Kelly BC (2013) Stimulated decomposition in peat for engineering applications. Proceedings of the ICE, Ground Improvement 166(3): 168-176, http://dx.doi. org/10.1680/grim.12.00003.

Radforth NW (1969) Classification of muskeg. In Muskeg Engineering Handbook (MacFarlane IC (ed.)). University of Toronto Press, Toronto, Ontario.

Raghu D and Hsieh HN (1986) Material properties of water treatment plant sludges. Civil Engineering for Practicing and Design Engineers 5(11/12): 927-941.
Raunkjaer K, Hvitved-Jacobsen T and Nielsen PH (1994) Measurement of pools of protein, carbohydrate and lipid in domestic wastewater. Water Research 28(2): 251-262.

Riley JL (1989) Laboratory Methods for Testing Peat OntarioPeatland Inventory Project. Ontario Geological Survey, Miscellaneous Paper \#145. Ministry of Northern Development and Mines, Ontario.

Sharma B and Bora PK (2003) Plastic limit, liquid limit and undrained shear strength of soil-reappraisal. ASCE Geotechnical and Geoenvironmental Engineering 129(8): 774-777.

Siedlungsabfall TA (1993) Dritte AllgemeineVerwaltungsvorschrift zum Abfallgesetz. Bundesanzeiger, Munich (in German).

Skempton AW and Petley DJ (1970) Ignition loss and other properties of peats and clays from Avonmouth, King's Lynn and Cranberry Moss. Géotechnique 20(4): 343-356.

Trauner L, Dolinar B and Misic M (2005) Relationship between the undrained shear strength, water content, and mineralogical properties of fine-grained soils. ASCE International Journal of Geomechanics 5(4): 350-355.

US EPA (2001) Method 1684: Total, Fixed, and Volatile Solids in Water, Solids, and Biosolids. EPA-821-R-01-015. U.S. Environmental Protection Agency, Washington, DC, USA.

Wang MC, Hull JQ, Jao M, Dempsey BA and Cornwell DA (1992) Engineering behavior of water treatment sludge. ASCE Journal of Environmental Engineering 118(6): 848-864.

Wichmann K and Riehl A (1997) Mechanical properties of waterwork sludges: shear strength. Water Science and Technology 36(11): 43-50.

Wood DM (1990) Soil Behaviour and Critical State Soil Mechanics. Cambridge University Press, New York, NY, USA.

Zentar R, Abriak N-E and Dubois V (2009) Fall cone test to characterize shear strength of organic sediments. ASCE Geotechnical and Geoenvironmental Engineering 135(1): 153-157.

Zhang L and O'Kelly BC (2014) The principle of effective stress and triaxial compression testing of peat. Proceedings of the ICE, Geotechnical Engineering. http://dx.doi.org/10.1680/ geng.12.00038. E-publication ahead of print.

\section{WHAT DO YOU THINK?}

To discuss this paper, please submit up to 500 words to the editor at journals@ice.org.uk. Your contribution will be forwarded to the author(s) for a reply and, if considered appropriate by the editorial panel, will be published as a discussion in a future issue of the journal. 